\title{
Pengembangan Konsep E-Government Syariah Berbasis Fiqih Siyasah
}

\author{
Siti Rahma Tiya1, Darius Antoni*1 \\ 1 Information System Departement, Bina Darma University, Palembang, Indonesia \\ IInformatics Departement, Bina Darma University, Palembang, Indonesia \\ Email: 1rahmatiya71@gmail.com,2darius.antoni@binadarma.ac.id
}

\begin{abstract}
Abstrak
Konsep E-government merupakan memberikan pelayanan kepada publik demi terjalinya komunikasi antara pemerintah dan masyarakat. Namun demikian masih sering terjadi ketidak seimbangan antara informasi yang di harapkan dengan informasi yang di sajikan oleh pemerintah terutama memlalui media eletronik. Oleh karena itu, pemerintah mengambil peluang menciptakan pelayanan yang berkualitas dengan memanfaatkan teknologi informasi yang disebut e-government. Konsep e-government dalam tinjauan Hukum Islam lebih mengarah kepada bagaimana cara mendayagunakan metode yang ditawarkan dalam IImu Ushul Fikih untuk merumuskan asas-asas Hukum Islam untuk merespon berbagai persoalan yang terjadi dalam pemerintahan. Pengedalian merupakan hal yang harus dilakukan agar tujuan yang telah direnacanakan dapat dilakukan dengan maksimal dalam memcapai target yang di inginkan. Sedangakan Pelaksanaan suatu makanisme atau intraksi antara pemerintah dengan masyarakat dan pihak-pihak yang terliabat. Kebijakan merupakan suata rangakian konsep dan asas menjadi suatu garis pelaksanan dalam pekerjaan, kebijakan harus ada dalam kehidupan bernegara. Dalam penelitian ini mengunakan Metode Kualitatif yang bersifat deskritip yang mengunakan Analisa dan mengacu pada data, atau bisa dilakukan dengan wawacaran dan observasi. Dalam pengembangan sistem ini meggunakan Framework Laravel dan MySQL sebagai Database. Dengan menggunakan Model MVC (Model View Controler) hasil dari penelitian ini merupakan aplikasi pelayanan terpadu berbasis website guna untuk mempermudahkan pemerintah dalam melakukan kontroling baik dalam semua kegiatan maupun transparansi dana. Selain itu, aplikasi ini juga dirancang untuk mempermudah masyarakat dalam berpartisipasi serta dalam aplikasi ini juga terdapat layanan publik yang berfungsi untuk mempermudah masyarakat berkomuikasi mau pun menyampaikan pendapat ke pemerintahan.
\end{abstract}

Kata Kunci: E-Government,Fiqih Siyasa, Framwork Laravel

\section{PENDAHULUAN}

Perkembangan teknologi yang sangat pesat. Setiap orang memerlukan teknologi untuk kebutuhan yang harus dimiliki contohnya teknologi informasi yang di 
manfaatkan oleh masyarakat dalam mendapat kan informasi saat ini. Sehingga pemerintah membuat keputusan untuk menciptakan layanan yang berkualitas dengan cara memanfaatkan teknologi informasi yang sering di sebut dengan egovernment. Seringkali Government dan government diangganp memiliki satu pengertian yang sama contohnya bagaimana proses dalam menerapkan kekuasaan dalam organisasi, lembaga maupun negara. Tetapi istilah dari egovernment dan governance memiliki makna yang berbeda. Govenment (pemerintahan) bermakna pada suatu kekuasaan di dalam negara. Sedangkan makna governance merupakan prosedur serta tata cara pemerintah untuk masyarakat dalam mengendalikan dan memecahkan masalah publik. [1]

Kota Palembang merupakan kota yang sudah mengimlementasikan egovernment dalam membantu berinteraksi dengan masyarakat.Pemerintah Kota Palembang talah banyak membuat aplikasi salah satunya yaitu Sidemang dan Hallo Palembang. Sidemang merupakan akronim dari sistem informasi administrasi online masyarakat kota palembang. Aplikasi Sidemang merupakan salah satu halaman website Hallo Palembang yang digunakan masyarakat secara mudah dalam pengurusan berkas tanpa harus datang ke kantor pemerintahan, masyarakat juga bisa mencetak sendiri berkasnya. Walaupun Kota Palembang telah mengimplementasikan banyak aplikasi e-government tetapi aplikasi-aplikasi tersebut belum mendukung visi Kota Palembang yaitu menjadi Palembang Emas Darusalam. Palembang Emas Darusalam yang memiliki dua kata yaitu EMAS yang mempunyai arti Elok Madani, Aman dan Sejahtera. Sedangkan kata DARUSSALAM mempunyai makna yaitu Kota Palembang akan menjadi Kota yang Aman, Damai, Makmur serta Sejahtera dengan keharmonisan antara kehidupan manusia dan alam. Untuk mendukung pemerintah Kota Palembang dalam mewujudkan Palembang Emas Darusalam dibutuhkan suatu konsep e-government berbasis Syariah [2].

Selain permasalahan di atas, jadi dibutuhkan suatu sistem e-govenment menurut administrasi Islam yaitu pengendalian, pelaksanaan dan kebijakan. Untuk menyelesaikan masalah tersebut maka akan dikembangkan menggunakan pendekatan maslahat mursalah atau fiqih siyasah. Dalam ilmu fiqih siyasah membahas cara mengatur tata negara secara Islam contohnya cara untuk menerapkan perundang-undangan serta peraturan lainnya yang sesuai dalam prinsip islam untuk menciptakan kemaslahan umum. Dari penjelasan di atas maka penelitian ini akan mengangkat judul yaitu "Pengembangan Konsep EGovernment Syariah Berbasis Fiqih Siyasah" yang mengacu pada Visi yang ada di Kota Palembang yaitu Palembang Emas Darusalam. 


\section{METODOLOGI PENELITIAN}

\subsection{E-Government}

E-government merupakan pembahasan tentang penggunaan teknologi informasi dan komunikasi (TIK) untuk mendefinisikan kembali layanan publik agar lebih mudah diakses, akuntabel, dan efektif. Ini meningkatkan efektivitas dan efisiensi organisasi publik dan meningkatkan akuntabilitas publik dan transparansi dalam pengambilan keputusan publik. Selain itu, e-government mendorong keterlibatan warga dalam administrasi publik karena sifat konsep e-government yang multidimensi. Hal ini mengarah pada identifikasi tiga klasifikasi utama e-government. Klasifikasi tersebut didasarkan pada sifat interaksi dalam sistem Government To Business (G2B), Government To Governments (G2G) dan Government To Citizens (G2C).[3]

1) Government to Business (G2B) merupakan interaksi antara pemerintah dan dunia usaha guna membantu bisnis dalam berurusan dengan pemerintah secara lebih efektif. Contoh yang paling umum adalah layanan pengadaan elektronik. Layanan ini memungkinkan proses penawaran transparansi untuk semua bisnis dimana sebelumnya bisnis ini perlu terus menghubungi pemerintah untuk pembaruan selama proses penawaran.

2) Government to Governments (G2G) memungkinkan berbagai informasi diantara organisasi publik hal ini berkaitan dengan pertukaran informasi antara lembaga pemerintah dan pegawai ditingkat provinsi dan lokal. Tujuan dari Government to Governments merupakan mencakup koordinasi yang lebih baik di antara badan pemerintah, prosedur standar dan efisiensi yang lebih besar bagi pemeritah untuk melayani publik dengan lebih baik.

3) Government to Citizens (G2C) berfokus pada interaksi antara pemerintah dan warga. Hal ini merupakan penggunaan e-government untuk meningkatkan penyampaian layanan publik. Contohnya Government to Citizens memungkinkan warga atau masyarakat dapat melakukan partisipasi berupa bantuan maupun berkomentar sehingga pemerintah dapat menanggapi komentar dari masyarakat itu sendiri.

\subsection{E-Government Di Kota Palembang}

Kota Palembang merupakan salah satu kota yang berusaha untuk mengembangkan e-government di dalam urusan administrasi pada pemerintahannya. Tetapi, penggunaan e-government di kota palembang masih banyak menghadapi berbagai masalah. Salah satu masalah yang dihadapi yaitu 
kurangnya keinginan dari masyarakat untuk memanfaatkan fasilitas pelayanan yang di sediakan oleh pemerintah dalam melakukan upaya penerapan egovenment sehingga hal ini masih belum bisa berjalan secara maksimal seperti yang diharapkan. Lokasi dan akses menjadi faktor penting dalam mendukung penerapan e-government untuk memberikan layanan kepada masyarakat. [4] Tabel 1 Aplikasi E-government Di Kota Palembang

\begin{tabular}{ccl}
\hline No $\quad$ Aplikasi & Deskripsi \\
\hline & Hallo Palembang merupakan wadah untuk masyarakat \\
& Kota Palembang dalam mendapatkan informasi \\
& Palembang & Pelayanan yang diberikan oleh seluruh Organisasi \\
& Perangkat Daerah di lingkungan Pemerintah Kota \\
& Palembang. \\
& Sidemang merupakan akronim dari sistem informasi \\
& administrasi online masyarakat kota palembang. Aplikasi \\
& Sidemang merupakan salah satu halaman website Hallo \\
& Palembang yang digunakan untuk mempermudah \\
& masyarakat dalam pengurusan berkas tanpa harus \\
& datang ke kantor pemerintahan masyarakat juga bisa \\
& mencetak sendiri berkasnya.
\end{tabular}

Menurut Antoni (2018) menginvestigasi e-government di Kota Palembang yang berjudul Information Technology Governance Profil of E-Government. Adapun hasil penelitiannya menunjukan bahwa:

1) Dalam aspek pengadaan dan pengembangan, ringkasan jawaban responden dalam penelitian yang telah dilakukan menunjuknan dalam pengembangan IT e-pemerintah, pemerintah Kota Palembang harus memperhatikan investasi dan sumber daya oprasional untuk meningkatkan pelaksanaan IT e-government di lingkungan pemerintahan.

2) Dalam aspek perencanaan dan pengorganisasian, ringkasan keseluruhan responden dalam penelitian yang telah dilakukan menunjukkan Palembang yang dalam hal IT e-pemerintah perencanaan masih kurang dalam penerapannya dan juga dalam hal pengorganisasian masih tampak kurang perhatian untuk pengembangan IT e-government di lingkungan pemerintahan.

3) Dalam aspek pelaksanaan dan manajemen, ringkasan keseluruhan responden dalam penelitian yang telah dilakukan menunjukkan bahwa dalam aspek pelaksanaan dan manajemen masih banyak yang belum diterapkan hanya karna terbatas pada perencanaan masa depan. 
4) Dalam aspek pengawasan dan pengembangan, ringkasan keseluruhan responden dalam penelitian yang telah dilakukan menunjukkan palembang dalam pengawasan dan pengembangan, masih ada kekurangan pada penghargaan dari segi IT e-government pembangunan sehingga e-government palembang masih tidak mampu untuk mendapatkan peringkat tertinggi dalam kompetisi IT e-government.

\subsection{Konsep E-Government Syariah Fiqih Siyasah}

Menurut (Nugraha, 2018) e-govenment merupakan penggunaan teknologi digital untuk mentransformasikan layanan kegiatan di pemerintahan dengan tujuan untuk meningkatkan penyampaian layanan efisiensi dan efektivitas. [5] Menurut Sri Warjiyati 2018 dalam pandangan Islam e-government merupakan bagaimana cara mengoprasikan metode yang ada di dalam ilmu Usul Fikih bertujuan untuk menyusun prinsip yang ada di dalam hukum islam untuk menanggapi persoalan yang terjadi didalam pemerintahan. Hubungan $e-$ government dan fiqih siyasah yaitu terletak pada bentuk pengendalian, pelaksanaan serta kebijakan di sebuah negara ataupun wilayah. Didalam ajaran figih siysah kebijakan maupun keputusan akan mengikuti ajaran islam maupun wahyu ilahi (top down) sedangkan good govenment merupakan sebuah pemikiran manusi (bottom up) [6].

\section{1) Pengendalian (Steering)}

Pengendalian merupakan sesuatu yang dilakukan agar tujuan yang telah di rencanakan dapat dilaksanakan dengan maksimal sehingga mencapai target yang di inginkan. Contohnya pendiri kantor pemda baru pasti memiliki tujuan tersendiri dalam menciptakan lembaga baru sehingga organisasi tersebut dapat mencapai tujuan yang belum bisa di capai oleh organisasi lama namun target tersebut membutuhkan rencana, program serta aktivitas utama yang akan dilakukan. Namun untuk mencapai rencana, program serta aktivitas tersebut memerlukan pengelolaan manajemen supaya tujuan dapat terpenuhi secara efektif dan efisien. Dibawah ini terdapat beberapa contoh pengendalian manajemen di pemerintahan yaitu:

a) Koordiasi, misalnya program bantuan sosial lintas kementrian/Lembaga dan Pemda.

b) Komunikasi, misalnya terdapat Rancangan Anggaran Pendapatan dan Belanja Negara (RAPBN) oleh kementrian keuangan dan pelaporan laporan kinerja.

c) Pengambilan keputusan, misalnya pilihan pelaksanaan proyek, alokasi dana saat bencana alam.

d) Pengendalian dan penilaian kinerja entitas tertentu, misalnya Laporan Akuntabilitas Kinerja Instansi Pemerintah (LAKIP) atau laporan kinerja lain. 
Dalam hal ini pemerintah diarahkan untuk melakukan pengendalian (steering) dan kolaborasi mengingat dinamika masyarakat seperti pola intraksi saling mengendalikan diantara berbagai faktor yang terlibat atau yang berkepentingan dalam suatu bidang tertentu. Pengendalian merupakan suatu yang bisa di monitoring atau yang bisa di kendalikan seperti evaluasi kinerja pegawai contohnya tugas apa saja telah di selesaikan, penilaian dan pengendalian bisa di lakukan dengan cara membuat program kerja seperti membuat jadwal atau target yang akan di laksanakan.

\section{2) Pelaksanaan}

E-government merupakan suatu mekanisme interaksi baru (moderen) antara pemerintah dengan masyarakat dan kalangan lain yang berkepentingan (stakeholder) yang melibatkan penggunaan teknologi informasi terutama internet dengan tujuan memperbaiki mutu atau kualitas layanan yang selama berjalan. Berdasarkan sifat transaksi informasi, pengembangan e-government dapat dilaksanakan melalui 4 tingkatan yaitu:

a) Persiapan, misalnya pembuatan situs informasi disetiap lembaga, penyiapan SDM dan penyiapan sarana akses yang mudah contohnya menyediakan sarana Multipurpose community Center, SME-Center, dan lain-lain, serta melakukan sosialisasi untuk situs informasi baik untuk internal maupun untuk publik.

b) Pematangan, misalnya pembuatan situs web informasi publik yang bersifat interaktif dan pembuatan antar muka keterhubungan dengan lembaga lain.

c) Pemantapan, misalnya pembuatan situs web yang bersifat transaksi pelayanan publik dan pembuatan interoperabilitas aplikasi dan data dengan lembaga lain.

d) Pemanfaatan, misalnya pembuatan aplikasi untuk pelayanan yang bersifat Government to Government (G2G), Government to Business (G2B), Government to Consumers (G2C) yang terintegrasi dan situs pemerintah pusat atau daerah harus secara bertahap ditingkatkan menuju ke tingkat-4.

Terkait dengan strategi tahapan pengembangan yang di laksanakan inpres, menurut Sri Handayaningsih (2007) pengembangan e-government dapat dilaksanakan melalui 4 (empat) tingkatan budaya yaitu Tahapan Inisiasi, Tahapan Interaksi, Tahapan Transaksi dan Tahapan Pelayanan. Hakikat pemerintahan yang baik dalam ajaran fikih, pada aturannya belum ditemukan pendekatan yang normal. Namun terdapat ayat yang mengidikasikan adanya persoalan pemerintahan yang baik dalam anjuran Islam. Hal itu dapat dilihat dalam firman Allah swt dalam surah al-Hajj/QS.22:41, 


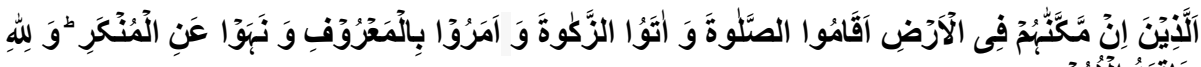

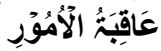

Al-ladziina in makkannaahum fiil ardhi aqaamuush-shalaata waaatawuuzzakaata wa-amaruu bil ma'ruufi wanahau 'anil munkari walillahi 'aaqibatul amuur(i);

Artinya : orang-orang yang jika Kami teguhkan kedudukan mereka di muka bumi niscaya mereka mendirikan sembahyang, menunaikan zakat, menyuruh berbuat ma'ruf dan mencegah dari perbuatan yang mungkar dan kepada Allah lah kembali segala urusan.

Dalam ayat tersebut tercantum arti yang menerangkan adanya permasalahan pada pemerintahan yang baik dalam pandangan fiqih, karena melaksanakan wewenang kekuasaan untuk mengelola pengembangan dengan berorientasi pada penata suasana kondusif bagi masyarakat dalam memenuhi keinginan spiritual dan rohani nya dapat ditandai dengan menegak kan sholat, menciptakan kemakmuran dan kesejahteraan ekonomi dapat dilambangkan dengan tindakan membayar zakat, serta menciptakan kestabilan politik dan keamanan dapat di ilhamkan dengan tindakan amar ma'ruf nahi munkar. Dengan demikian dalam ayat tersebut menyusun pemerintahan yang baik dengan beberapa aspek yaitu Spiritual Governance, Economic Governance dan Political governance.

\section{3) Kebijakan}

Sesuai dengan instruksi Presiden Republik Indonesia No 03 tahun 2003 tentang kebijakan dan strategi Nasional pengembangan e-government yang menyebutkan terb entuknya kepemerintahan yang bersih, transparan dan mampu menjawab tuntutan perubahan secara efektif yaitu:

1. Masyarakat menuntut pelayanan publik yang memenuhi kepeningan masyarakat luas di seluruh wilayah negara dapat diandalkan dan terpercaya serta mudah dijangkau secara interaktif.

2. Masyarakat menginginkan agar asiprasi mereka di dengar dengan demikian pemerintah harus memfasilitasi partisipasi dan dialog publik di dalam perumusan kebijakan negara.

Beberapa contoh penerapan e-govenment yang ada di Indonesia yaitu One Stop Service (OSS) yang merupakan layanan perijinan terpadu dan E-Procurement yang menampilkan informasi proyek pemerinntah secara terbuka sehinggaa masyarakat dapat turut serta untuk melakukan tender proyek tersebut. Egovernment tentunya akan meningkatkan pelayanan kepada masyarakat. Salah satu perusahaan yang sudah mendukung e-government yaitu Gamatecho melalui beberapa layanan seperti mCity dan gtPerijinan. 
Dalam prespektif hukum Islam, pemerintahan yang baik dapat dikatakan sebagai sebuah ijtihad yang dilakukan dalam rangka mencapai maslahah yang menjadi tujuan syari'at (maqashid syariah). Maslahah tersebut adalah terciptanya suatu penyelenggaraan manajemen pembangunan yang solid dan bertanggungjawab yang sejalan dengan prinsip demokrasi dan pasar yang efisien, penghindaran salah alokasi dana investasi, dan pencegahan korupsi baik secara politik maupun administratif menjalankan disiplin anggaran serta penciptaan legal and political frame work bagi tumbuhnya aktivitas usaha. Dalam konsep maslahah juga dibahas dalam kaidah qowaid fiqiyah, yaitu:

\section{تصرف الامام علي الرا عية منو ط بالمصلحة}

Artinya : "kebijakan seorang pemimpin terhadap rakyatnya adalah berkaitan dengan Kemaslahatan".

Kaidah ini adalah kaedah khusus dalam bidang siyasah. Maksud kaedah ini adalah tindakan pemerintah harus berorientasi pada kemaslahatan umat. Good governance yang diwacanakan dan diterapkan dalam birokrasi sebagai sebuah upaya dari pemerintah dan masyarakat merupakan sebuah tindakan yang berorientasi maslahah. Penguatan nilai-nilai akuntabilitas, transparansi, supremasi hukum, dan partisipasi publik dalam pelaksanaan birokrasi publik menjadikan lembaga semakin kuatdan dapat menghasilkan manfaat yang maksimal.

Berdasarkan penjelasan pada penelitian yang dibuat maka dapat diambil kesimpulan bahwa konsep e-government syariah fiqih siyasah memiliki 3 tahapan yaitu pengendalian, pelaksanaan dan kebijakan pada tabel 1.1 dibawah ini akan dijelaskan secara singkat tentang atribut apa saja yang terdapat pada tahapan-tahapan tersebut.

Tabel 2 Kesimpulan dari pengendalian, pelaksanaan dan kebijakan

No E-government Fiqih Siyasah

\begin{tabular}{lll}
\hline & Sesuatu yang di monitor atau yang bisa dikendali \\
& kan seperti evaluasi kinerja pengawai misalnya \\
& membuat jadwal atau target yang akan di \\
& laksanakan. \\
& Target apa saja yang telah di lakukan oleh \\
& pemerintah dari program kerja yang telah di \\
tentukan pemerintah.
\end{tabular}

Atribut 


\section{No E-government Fiqih Siyasah \\ Atribut \\ $3 \quad$ Kebijakan \\ Peraturan perundang-undangan yang telah di buat oleh pemerintah.}

\subsection{Metode Penelitian}

Untuk memperoleh data yang dibutuhkan dilakukan dengan metode pengumpulan data sebagai berikut:

a. Pengamatan (Observasi) yaitu melakukan penggamatan e-government yang sudah ada di Kota Palembang untuk mendapatkan gambaran umum situasi implementasi e-government di Kota Palembang.

b. Wawancara (Interview) merupakan salah satu cara pengumpulan data yang di lakukan dengan cara mengajukan pertanyaan kapada beberapa masyarakat contoh nya Alim Ulama untuk mengetahui Hukum secara Islam.

c. Dokumentasi (Documentation) merupakan document atau tulisan jadi dapat di artikan metode dokumentasi berarti pengumpulan data dengan cara mencatat atau merecord data-data yang ada. Metode dokumentasi ini merupakan data yang berubungan dengan hal-hal atau variabel contohnya buku catatan, surat, transkip surat atau berupa artikel di internet dan laporan yang sesuai dengan permasalahan.

\subsection{Metode Pengembangan Sistem}

Pada tahap ini peneliti menggunakan metode pengembangan sistem dengan model Prototype. Prototype adalah sebuah metode pengembangan software yang banyak digunakan pengembang agar dapat saling berinteraksi dengan pelangan selama proses pembuatan sistem. [7]

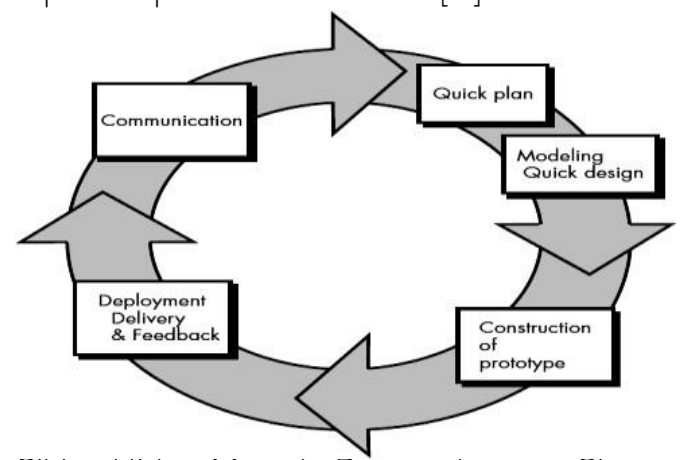

Gambar 1. Siklus Hidup Metode Pengembangan Sistem Prototyping [7] 
Berdasarkan model prototype yang telah digambarkan diatas, maka dapat diuraikan pembahasan masing-masing tahap dalam model tersebut adalah sebagai berikut :

1) Komunikasi, Tim pengembang perangkat lunak melakukan pertemuan dengan para stakeholder untuk menentukan kebutuhan perangkat lunak apa saja yang akan digunakan dalam pembuatan sistem.

2) Perencanaan, Pengembang membuat perencanaan mengenai prototype yang akan dibuat yang berfokus pada gambaran umum situasi implementasi e-government di Kota Palembang.

3) Model Rancangan, Pengembang membuat rancangan prototype yang berfokus pada kebutuhan masyarakat.

4) Pembuatan Prototype, Dalam tahapan ini prototyping yang sudah di sepakati diterjemahkan ke dalam bahasa pemograman yang sesuai atau di kehendaki.

5) Penyebaran, Pengujian Dan Umpan Balik, Setelah sistem sudah menjadi satu perangkat yang siap dipakai, harus dites dahulu sebelum digunakan.

\section{HASIL DAN PEMBAHASAN}

\subsection{Perancangan Sistem}

1) Usecase Diagram

Usecase Diagram merupakan bagaimana alur yang akan dilakukan di dalam sistem website yang dibangun serta aktor mana saja yang dapat berinteraksi dengan sistem. Usecase diagram merupakan alur kerja dari Admin/Pemerintah, Rt dan Masyarakat. Dibawah ini merupakan usecase diagram dari website yang akan di buat. Adapun hasil Usecase diagram yang dibuat bisa dilihat pada gambar dibawah ini :

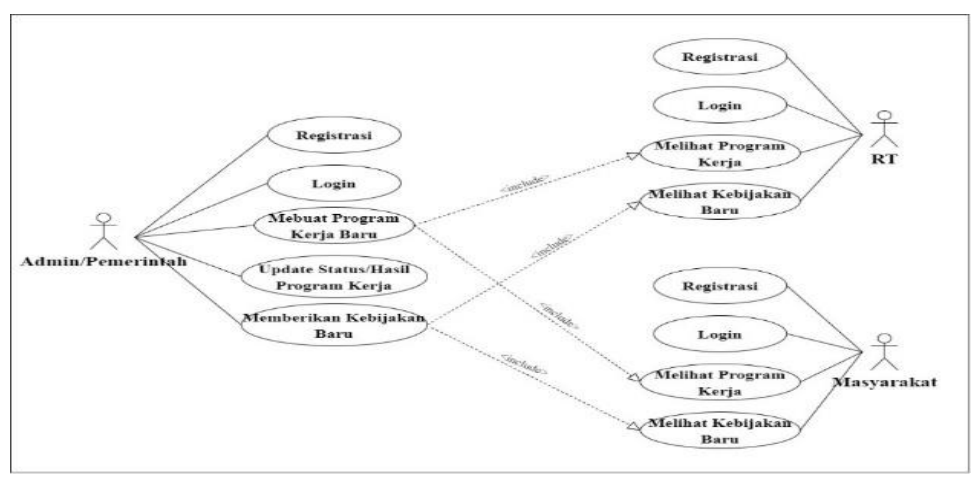

Gambar 1. UseCase Diagram 


\section{2) Class Diagram}

Class Diagram adalah rancangan database pada sistem yang akan dibuat serta menampilkan berbagai kelas yang ada di dalam aplikasi yang akan dibuat. Class diagram merupakan gambaran relasi tabel di dalam aplikasi yang dibangun. Adapun hasil class diagram yang dibuat bisa dilihat pada gambar dibawah ini :

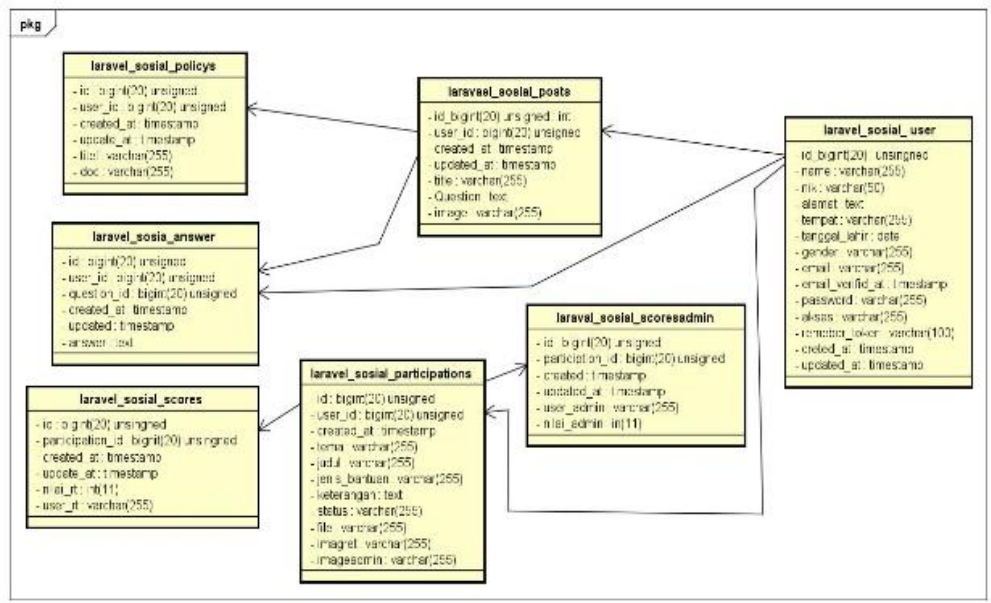

Gambar 2. Class Diagram

\section{3) Activity Diagram}

Activity Diagram Registrasi Admin/Pemerintah, Merupakan penjelasan proses apa saja yang harus dilakukan oleh admin/pemerintah saat ingin mendapatkan hak izin akses login di website yang akan digunakan. Untuk lebih detailnya dapat dilihat pada gambar dibawah ini :

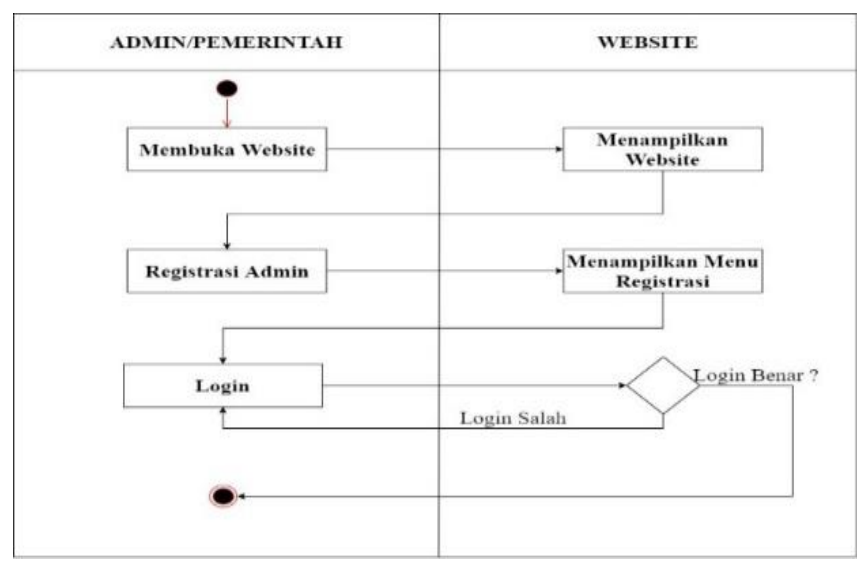

Gambar 3. Actifity Diagram Registrasi Admin/Pemerinta 
Activity Diagram Program Kerja Pemerintah, Merupakan penjelasan mengenai langkah-langkah apa saja yang harus di lakukan admin/pemerintah saat ingin membuat program kerja pemerintah di website yang akan digunakan. Untuk lebih detailnya dapat dilihat pada gambar di bawah ini :

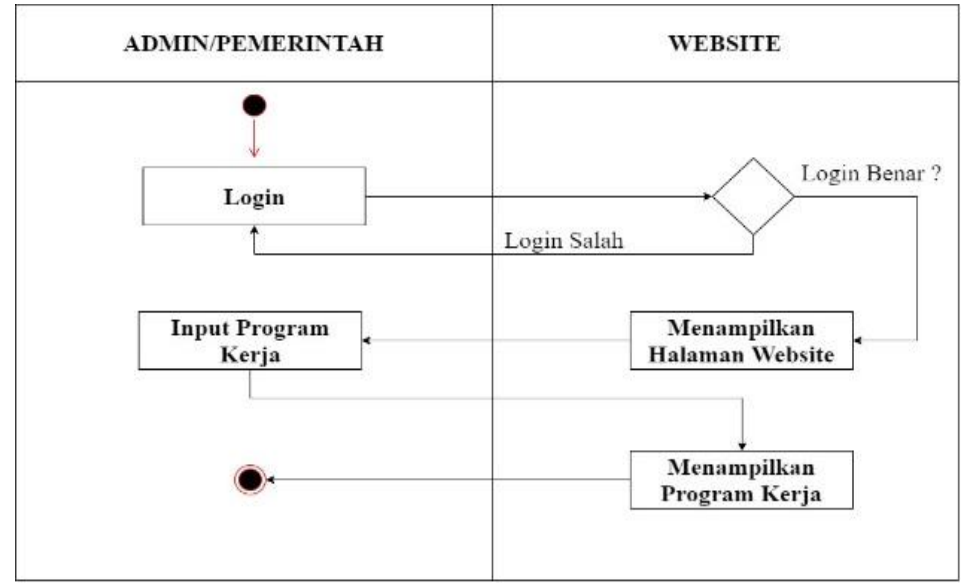

Gambar 4. Actifity Diagram Program Kerja Pemerinta

Activity Diagram Update Hasil Program Kerja, Merupakan penjelasan mengenai langkah-langkah apa saja yang harus di lakukan admin/pemerintah saat ingin melakukan update pada hasil program kerja yang telah di lakukan oleh pemerintah di website yang akan digunakan. Untuk lebih detailnya dapat dilihat pada gambar di bawah ini :

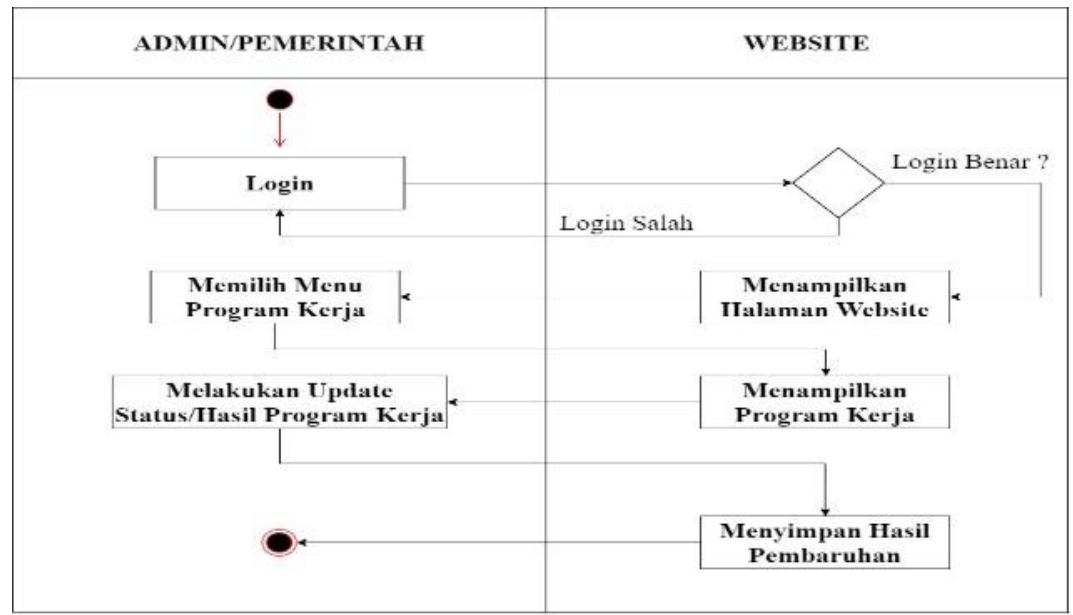

Gambar 5. Actifity Diagram Update Hasil Program Kerja 
Activity Diagram Kebijakan Terbaru, Merupakan penjelasan mengenai langkahlangkah apa saja yang harus di lakukan admin/pemerintah saat ingin membuat kebijakan baru di website yang akan di lakukan. Untuk lebih detainya dapat dilihat pada gambar di bawah ini :

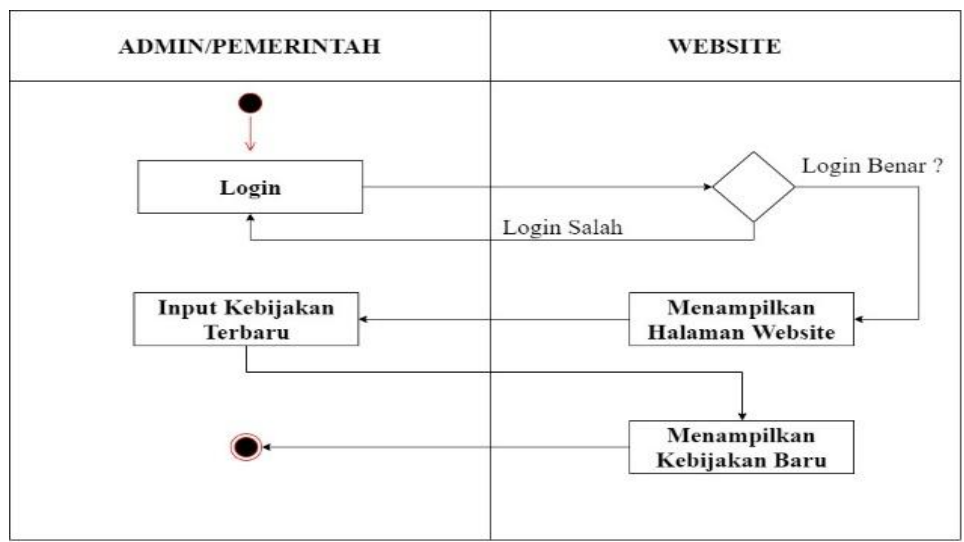

Gambar 6. Actifity Diagram Kebijakan Terbaru

\subsection{Implementasi}

Implementasi pada aplikasi ini merupakan hasil dari rancangan dan desain yang telah di lakukan di bab sebelumnya. Aplikasi yang di bangun menggunakan bahasa pemograman PHP serta fremwork Larave/ dengan menggunakan kedua teknologi tersebut maka aplikasi yang di bangun dapat di jalankan pada web browser.

\subsection{Pengujian Sistem}

Pengujian sistem yaitu proses pengujian sistem yang dibangun apakah sudah sesuai dengan yang telah di tentukan dan apakah layak untuk digunakan. Pengujian sistem dilakukan dengan cara menguji setiap proses dengan kemungkinan terdapat kesalahan di setiap prosesnya.

\subsection{Implementasi Tampilan}

1) Tampilan Interface Regestrasi, Form registrasi merupakan langkah awal untuk mendapatkan hak akses masuk setelah aplikasi terbuka. Pemerintah, RT maupun Masyarakat diwajibkan untuk melakukan registrasiagar bisa melanjutkan ke halaman utama. 
Journal of Information Technology Ampera

Vol. 1, No. 3, December 2020 e-ISSN: 2774-2121

https://journal-computing.org/index.php/journal-ita/index

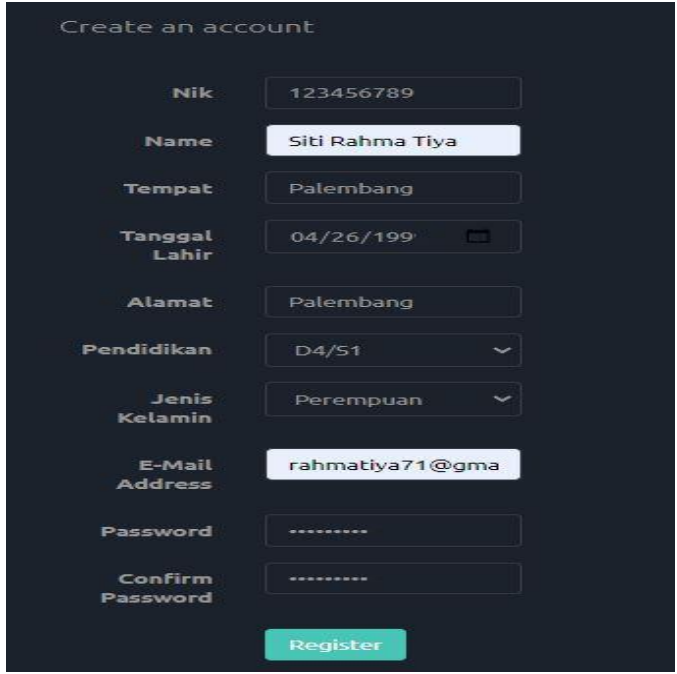

Gambar 7. Tampilan Interface Regestasi

2) Tampilan Interface Login, Form login merupakan langkah untuk masuk ke halaman dashbord di website yang di buat. Admin/pemerintah, RT dan Masyarakat harus memasukkan E-mail serta Password agar bisa masuk ke halaman utama website.

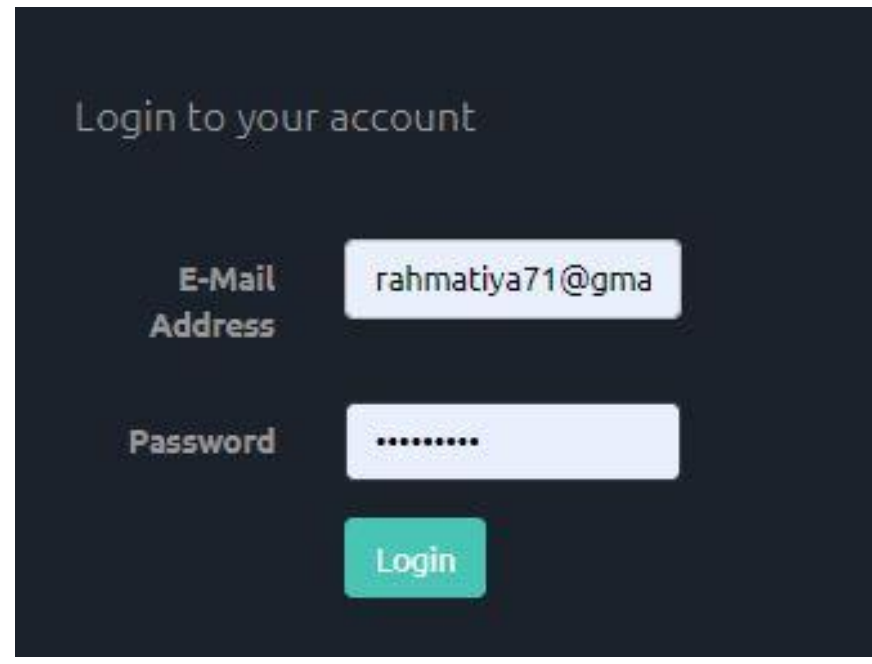

Gambar 8. Tampilan Interface Login

3) Tampilan Form Dashbord Admin, Halaman dashbord merupakan halaman yang akan ditampilkan setelah admin login. Terdapat beberapa menu yang di perlukan oleh admin yaitu Pengendalian, Score RT, Score Admin, Thema 
Partisipasi, Help Partisipasi, Forum, Upgrade User, Kebijakan, Laporan, Dokumen File.

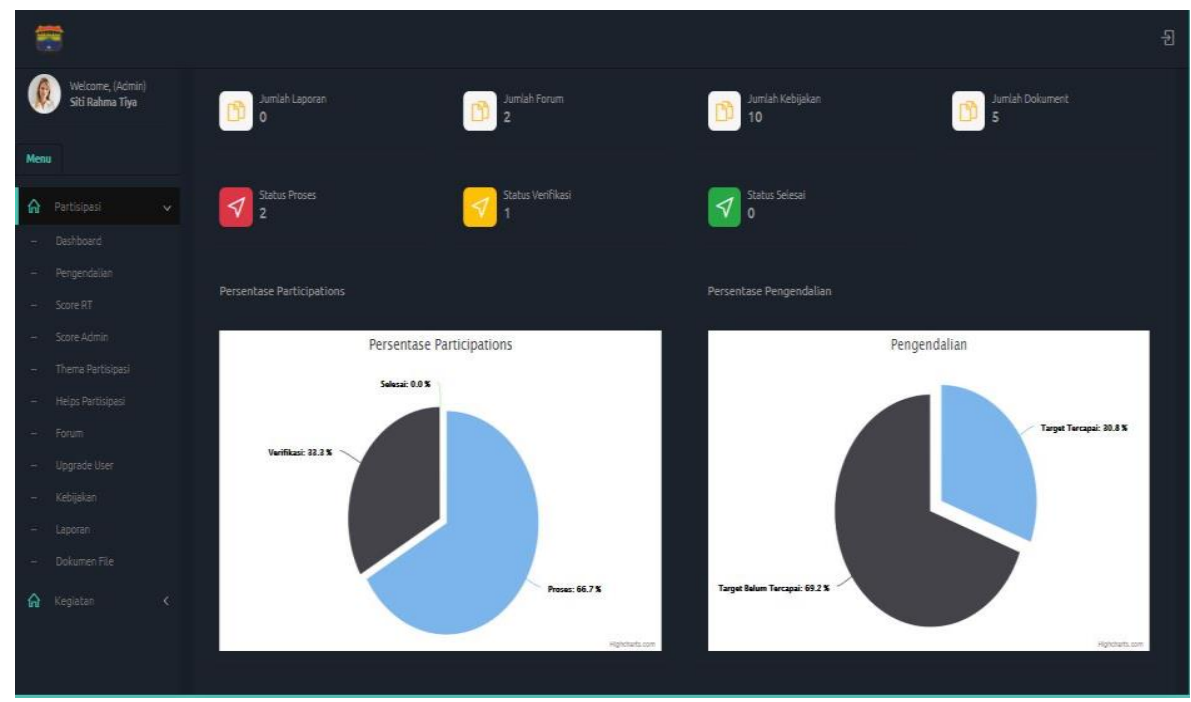

Gambar 9. Form Dashboard Admin

4) Tampilan Form Menu Pengendalian, Halaman Pengendalian merupakan halaman hasil input pengendalian atau program kerja pemerintah. Pada halaman ini dapat melihat program kerja apa saja yang telah dilakukan serta pada halaman ini dapat melakukan update program kerja jika dirasa program kerja telah diselesaikan.

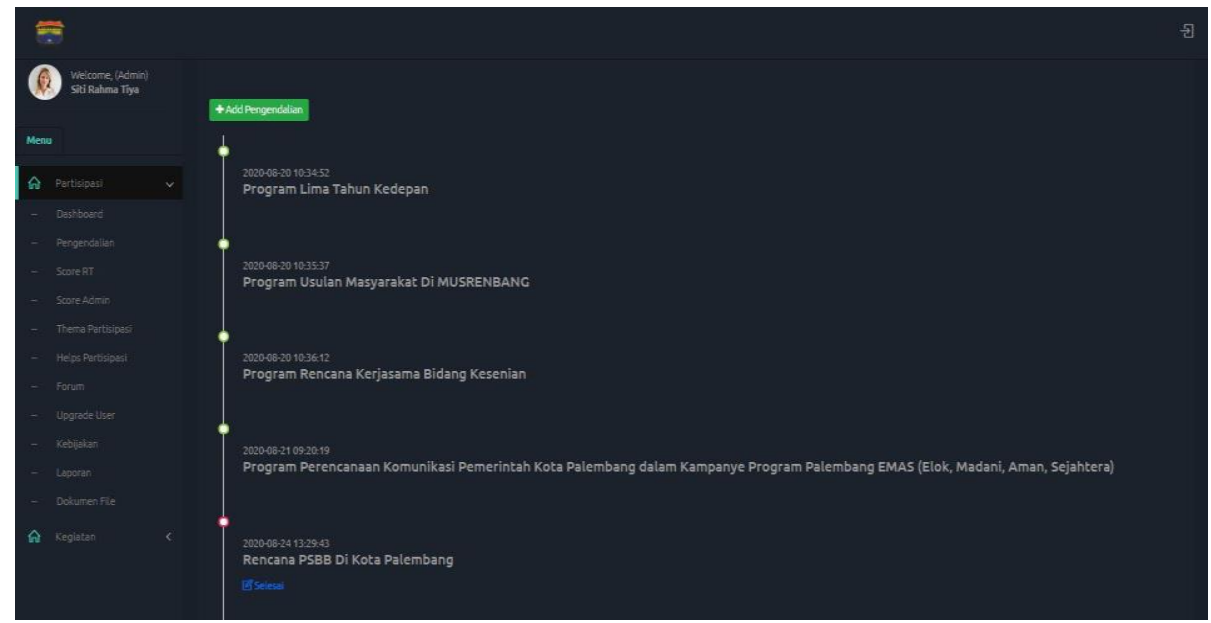

Gambar 10. Form Menu Pengendalian 
5) Tampilan Form Tambah Pengendalian, Tambah pengendalian merupakan menu yang digunakan untuk menambahkan pengendalian/program kerja baru yang direncanakan oleh pemerintah.

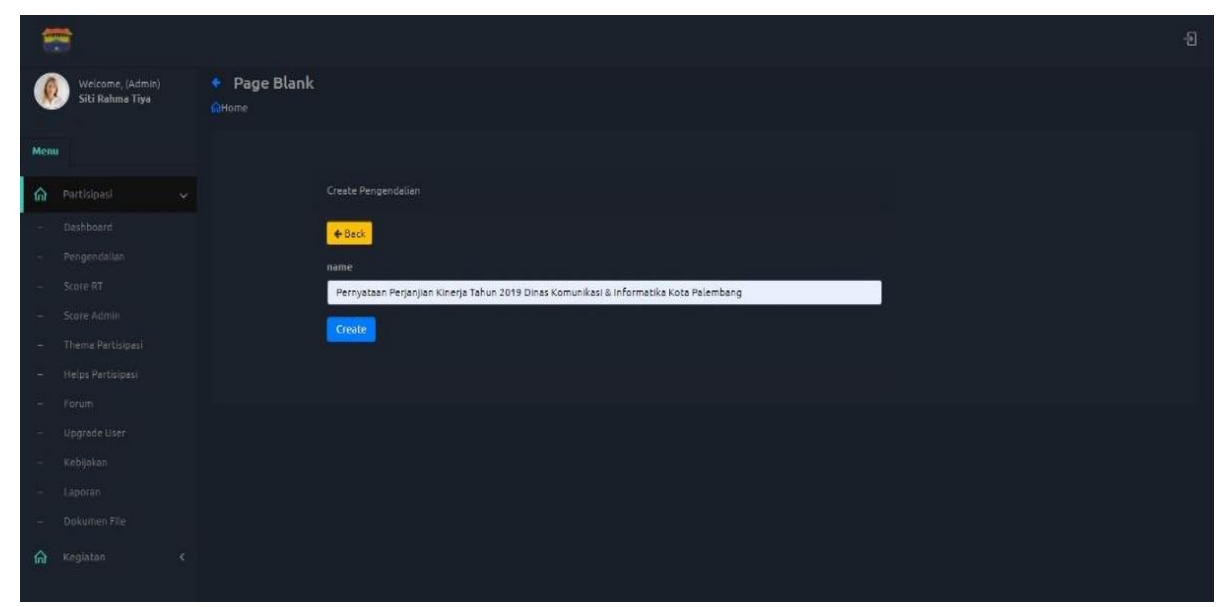

Gambar 11. Form Tambah Pengendalian

6) Tampilan Form Menu Kebijakan, Halaman kebijakan merupakan halaman yang terdapat kebijakan-kebijakan yang dikeluarkan oleh pemerintah sehingga admin menginputkan di halaman ini agar masyarakat dapat melihat kebijakan apa saja yang di keluarkan oleh pemerintah.

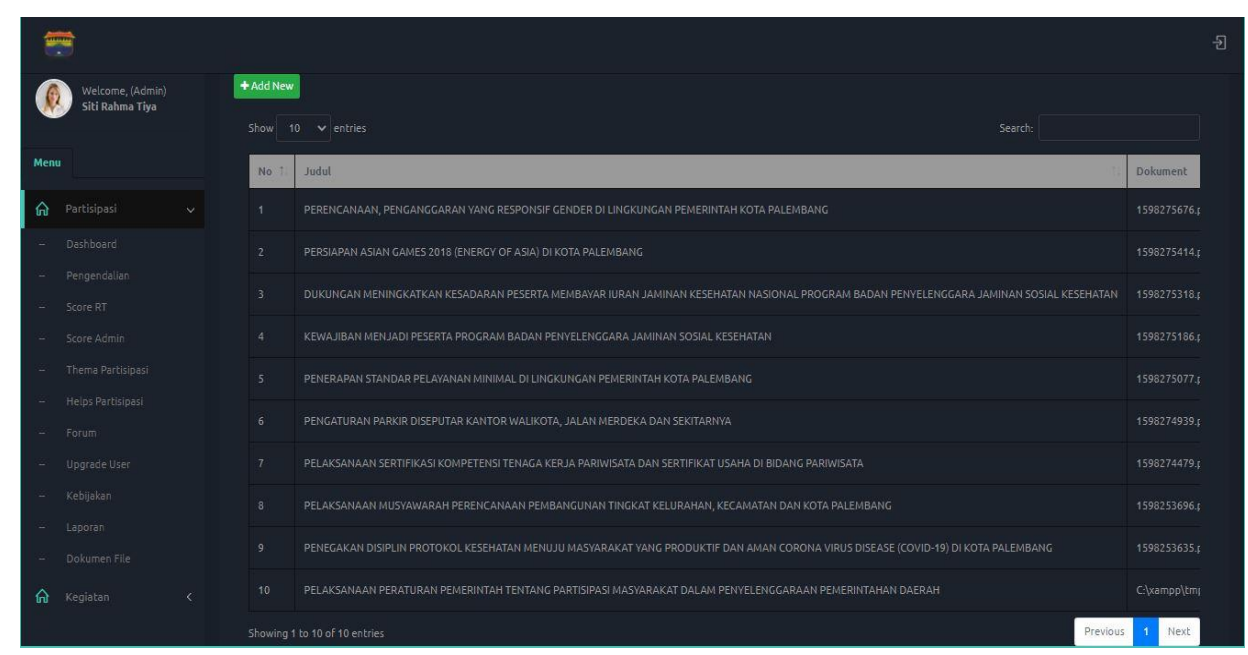

Gambar 12. Form Menu Kebijakan 
7) Tampilan Form Tambah Kebijakan, Pada halaman tambah kebijakan digunakan untuk menambahkan kebijakan baru yang di keluarkan pemerintah untuk masyarakat.

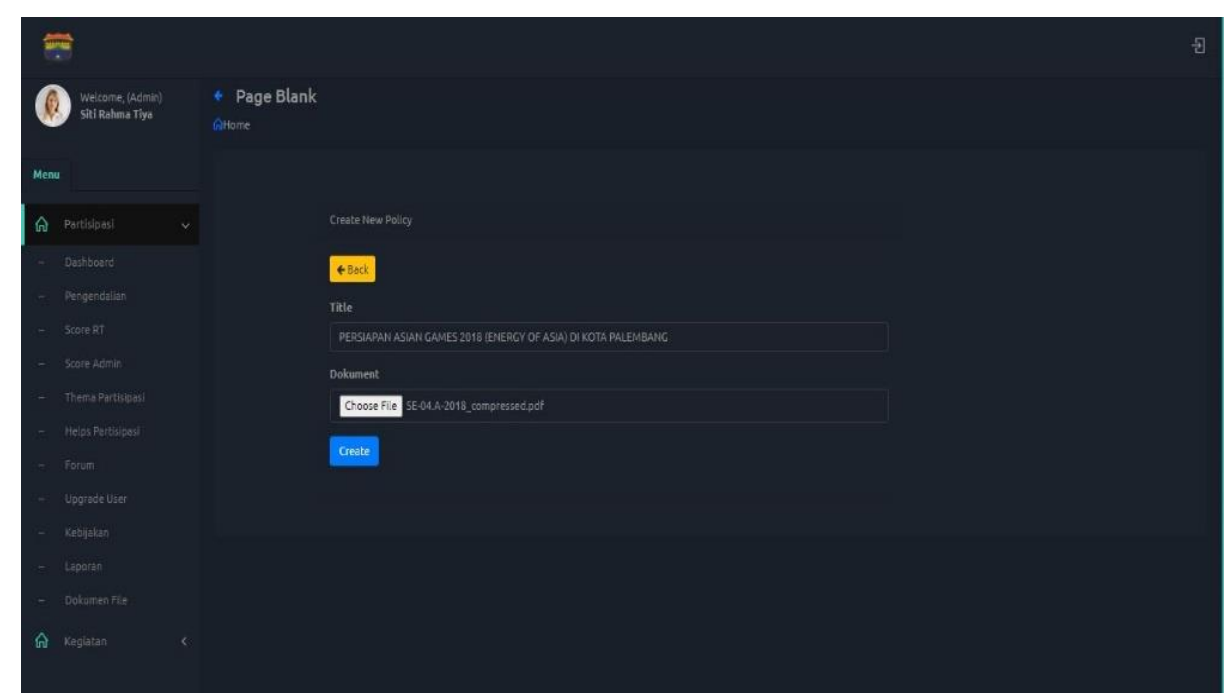

Gambar 13. Form Tambah Kebijakan

\section{KESIMPULAN}

Kualitas pelayanan adalah salah satu hal penting dalam memberikan kepuasan terhadap pengguna layanan tersebut. Pemerintah dituntut untuk dapat memberikan pelayanan yang baik terhadap masyarakat sehingga pemerintah mendapatkan feedback dari proses pelayanan tersebut guna sebagai bahan evaluasi di penelitian selanjutnya. Adapun hasil dari penelitian ini merupakan aplikasi pelayanan terpadu berbasis website guna untuk mempermudahkan pemerintah dalam melakukan kontroling baik dalam semua kegiatan maupun transparansi dana. Selain itu, aplikasi ini juga dirancang untuk mempermudah masyarakat dalam berpartisipasi serta dalam aplikasi ini juga terdapat layanan publik yang berfungsi untuk mempermudah masyarakat berkomuikasi mau pun menyampaikan pendapat ke pemerintahan.

\section{DAFTAR PUSTAKA}

[1] A. Bardadi and M. A. Firdaus, "Pengembangan Sistem Informasi Manajemen Perkuliahan Pada Fakultas IImu Komputer Universitas Sriwijaya," Jurnal Sistem Informasi, vol. 2, no. 1, p. 10, 2010. 
[2] E. Sudarsono, D. Antoni, and M. Akbar, "Tatakelola Green E-Government Di Kota Palembang," p. 6, 2018.

[3] A. Sabani, H. Deng, and V. Thai, "Evaluating the Development of EGovernment in Indonesia," p. 5.

[4] "1st Revised IT Governance of E-government in Palembang.en.id.docx." .

[5] "E-Government Dan Pelayanan Publik (Studi Tentang Elemen Sukses Pengembangan E-Government Di Pemerintah Kabupaten Sleman) (1).pdf." .

[6] S. Warjiyati, "Tinjauan Hukum Islam Terhadap Penerapan Good Governance Dalam Pelayanan Publik," HUKUM ISLAM, vol. 18, no. 1, p. 119, Oct. 2018, doi: 10.24014/hi.v18i1.5429.

[7] H. N. Syaddad, "Rancang Bangun Digital Archiving Di Perguruan Tinggi Menggunakan Metode Prototype Model Studi Kasus: Universitas Suryakancana," p. 9, 2017. 